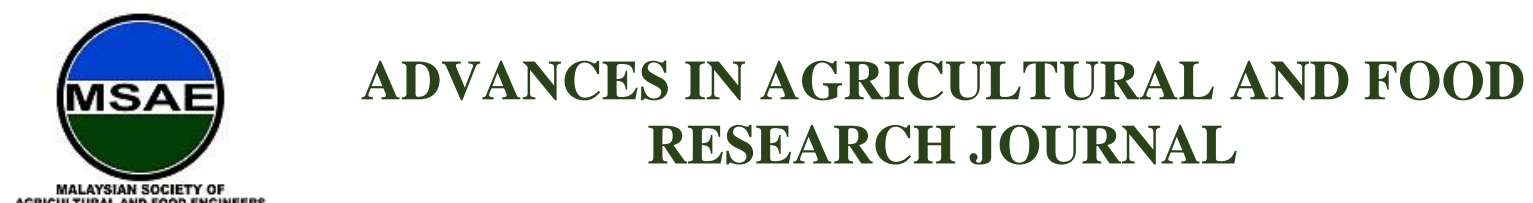

HH PUBLISHER

Original Research Article

\title{
Pemantauan Tanaman Padi Menggunakan Sistem Maklumat Geografi dan Imej Multispektral
}

Rowena Mat Halip ${ }^{1}$, Nik Norasma Che'Ya ${ }^{*}$, Wan Fazilah Fazlil Ilahi ${ }^{1}$, Rhushalshafira Rosle ${ }^{1}$, Nor Athirah Roslin¹, Mohd Razi Ismail², Zulkarami Berahim³ dan Mohamad Husni Omar ${ }^{3}$

${ }^{1}$ Department of Agriculture Technology, Faculty of Agriculture, Universiti Putra Malaysia, 43400 Serdang, Selangor, Malaysia

${ }^{2}$ Department of Crop Science, Faculty of Agriculture, Universiti Putra Malaysia, 43400 Serdang, Selangor, Malaysia

${ }^{3}$ Laboratory of Climate-Smart Food Crop Production, Institute of Tropical Agriculture and Food Security, Universiti Putra Malaysia, 43400 Serdang, Selangor, Malaysia

*Corresponding author: Nik Norasma Che'Ya, Department of Agriculture Technology, Faculty of Agriculture, Universiti Putra Malaysia, 43400 Serdang, Selangor, Malaysia; niknorasma@upm.edu.my

\begin{abstract}
This study is focused on paddy growth monitoring using Geographic Information System (GIS) and multispectral imagery via unmanned aerial vehicle (UAV). The objective of the study is to identify the best treatment that produces the highest yield. This combined technology is an effective farming management known as precision farming. UAV was used as a tool for field data capturing to produce orthophoto which will be a source for vegetative index and also for vector data digitizing purposes using ArcGIS 10.2. Data will be used as a source to analyze and monitor paddy growth. Geographical features that are digitized will able to provide farmer a full visual of their crop area such as crop layout, treatment type and also vegetative index. As a result, plot with treatment type Compost with Inoculum is able to produce the highest yield with $24947.73 \mathrm{~kg} / \mathrm{ha}$ yield comparing to other treatment plots. Treatment - U Grow producing the highest NDVI reading which is 0.4327 with yield producing only $2411.31 \mathrm{~kg} / \mathrm{ha}$ lower than the plot with treatment type Compost with Inoculum. Analytical images have shown that the high NDVI reading rate indicates that the paddy is still actively carrying out photosynthesis activities and is not yet ready to be harvested. Therefore, this research has shown that vegetative index value is able to become a benchmark for paddy growth monitoring while spatial analysis is able to make farming management more efficient. Other factors such as terrain model and effectiveness of current irrigation system can be a next sub topic for the research.
\end{abstract}

\begin{abstract}
Abstrak: Kajian ini memfokuskan kepada pemantauan pertumbuhan tanaman padi menggunakan sistem maklumat geografi (GIS) dan imej multispektral dengan menggunakan kaedah alatan pemanduan tanpa pesawat (UAV). Ianya bertujuan untuk mengenal pasti jenis rawatan yang mampu memberi hasil pengeluaran padi yang tinggi. Kombinasi teknologi ini merupakan kaedah pengurusan ladang yang lebih efektif dikenali sebagai pertanian tepat. UAV diguna pakai sebagai alatan untuk pencerapan data lapangan untuk menghasilkan peta ortofoto yang seterusnya digunakan untuk menghasilkan indeks tumbuhan dan pendigitan data vektor menggunakan perisian ArcGIS 10.2. Data vektor dan indeks tumbuhan ini seterusnya dapat digunakan untuk analisis pemantauan pertumbuhan tanaman padi.
\end{abstract}


Maklumat geografi yang didigitalkan dalam bentuk pemetaan dapat memberi visual penuh kepada peladang tentang tanaman padi mereka seperti susun atur petak sawah, jenis pembajaan dan juga bacaan indeks tumbuhan. Hasil kajian mendapati bahawa plot rawatan jenis kompos dengan inokulum mengeluarkan hasil yang paling tinggi iaitu $2494.73 \mathrm{~kg} / \mathrm{ha}$ berbanding plot dengan rawatan yang lain. Plot rawatan $U$ Grow memberi bacaan nilai maksimum NDVI yang paling tinggi iaitu 0.4677 dan mengeluarkan hasil tuaian hanya $2411.31 \mathrm{~kg} / \mathrm{ha}$ lebih rendah daripada plot rawatan kompos dengan inokulum. Imej analisis telah menunjukkan bahawa kadar bacaan NDVI yang tinggi menandakan pokok padi tersebut masih aktif menjalankan aktivi fotosintesis dan masih belum sedia untuk dituai. Justeru, kajian menunjukkan bahawa indeks bacaan tumbuhan boleh dijadikan sebagai penunjuk aras untuk pemantauan pertumbuhan tanaman padi dan analisis spatial mampu memudahkan tadbir urus ladang.

Keywords: GIS; UAV; imej multispektral; NDVI; indeks tumbuhan

Received: $28^{\text {th }}$ May 2020

Accepted: $4^{\text {th }}$ September 2020

Cition: Mat Halip R, Che Ya NN, Fazli Ilahi WF, et al. Pemantauan tanaman padi menggunakan sistem maklumat geografi dan imej multispektral. Adv Agri Food Res

Published: $30^{\text {th }}$ September 2020 https://doi.org/10.36877/aafrj.a0000118

\section{Pengenalan}

Lembaga Kemajuan Pertanian Kemubu (KADA) merupakan satu badan kerajaan yang diwujudkan pada tahun 1972. Salah satu fungsi kewujudan lembaga ini adalah untuk memenuhi keperluan beras nasional (Kementerian Pertanian dan Industri Asas Tani, 2019). Beras merupakan makanan ruji bagi rakyat Malaysia dan kerajaan harus memastikan pengeluaran beras mampu menampung keperluan negara. Berdasarkan Statistik Tanaman (Sub-Sektor Tanaman Makanan) 2019 yang dikeluarkan oleh Jabatan Pertanian Semenanjung Malaysia, hasil pengeluaran KADA tidak menunjukkan hasil pengeluaran padi dari tahun 2015 hingga 2019 (Gambar rajah 1).

Berdasarkan statistik yang diterima, hasil pengeluaran beras masih tidak memenuhi sasaran kerajaan sebanyak 8 hingga 12 t/ha setahun (Abd Mutalib, 2019). Faktor penyumbang kepada hasil pengeluaran padi yang rendah adalah seperti keadaan cuaca, bekalan air, serangga dan penyakit. Sesetengah peladang didapati menghadapi kesukaran pada kerja-kerja tadbir urus ladang dalam skala yang besar (Norasma et al., 2018). Pada tahun 2019, kerajaan telah melancarkan program yang dikenali sebagai Halatuju Kementerian Pertanian dan Industri Asas Tani: Prioriti \& Strategi 2019-2020. Antara agenda yang disarankan adalah perlaksanaan pertanian tepat dengan memperkenalkan penggunaan teknologi baharu dan juga pengukuhan sistem tadbir urus ladang yang lebih sistematik. Ianya bertujuan untuk meningkatkan hasil pengeluaran padi pada peringkat nasional. 


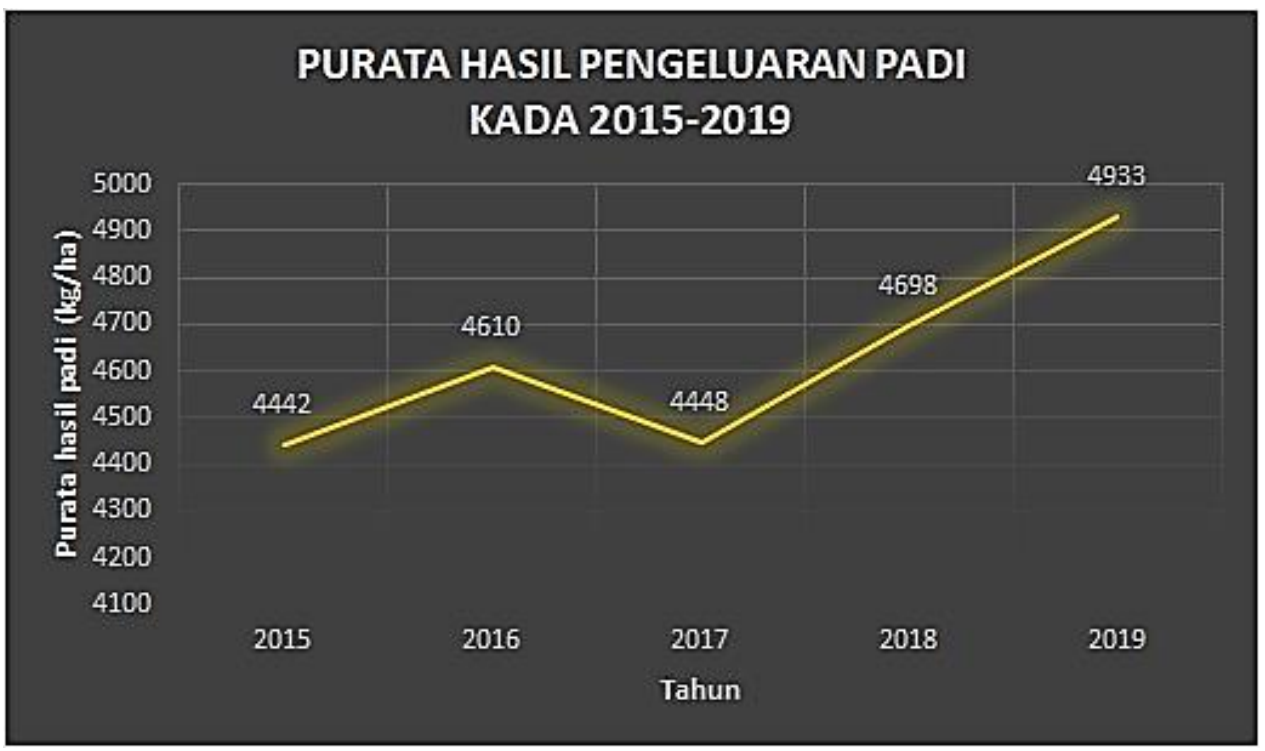

Gambar rajah 1. Purata hasil pengeluaran padi KADA yang dicatat (Jabatan Pertanian, 2019)

Pertanian tepat memberi kelebihan kepada peladang dari segi mengurangkan kos operasi, mengoptimumkan hasil dan kualiti serta mampu memberi informasi yang lebih terperinci untuk pengurusan yang lebih baik (Srinivasan, 2006). Ketepatan data bagi tujuan pertanian tepat hanya boleh dicapai melalui analisis dari data yang tepat juga (Sabarina \& Priya, 2015). Penggunaan alatan pemanduan tanpa pesawat (UAV) disarankan dalam agenda kerajaan. UAV yang dilengkapi dengan kamera mampu memberi gambaran plot tanaman secara menyeluruh (Murugan et al., 2016). Sistem maklumat geografi (GIS) dan teknologi penginderiaan jarak jauh (Remote Sensing atau RS) diguna pakai dalam kajian ini sebagai elemen bantuan untuk penambahbaikan pengurusan ladang. Pengambilan data menggunakan UAV dan kamera multispektral mampu menghasilkan bacaan Normalized Difference Vegetation Index (NDVI) yang beresolusi tinggi.

Bacaan NDVI ini banyak diguna pakai dalam bidang pertanian untuk tujuan anggaran pengeluaran padi dan juga keberkesanan rawatan yang diberi (Guan et al., 2019). Bacaan indeks tumbuhan digunakan secara meluas dalam bidang pertanian untuk mengukur kadar pertumbuhan tanaman sama ada tanaman dalam keadaan baik atau tidak (Ghobadifar, 2015). Pigmen daun pada tanaman akan memantulkan 'near infrared light' (NIR) dan menyerap 'visible wavelength'. Kadar kepekatan warna hijau memberi indikasi bahawa tanaman adalah sihat (Mahajan \& Bundel, 2017). Setiap tanaman mempunyai nilai julat NDVI yang unik. Dengan menggunakan sistem GIS, julat NDVI yang dihasilkan terbukti mampu untuk mengklasifikasikan tanaman yang berbeza (Bhumika et al., 2019). Kajian ini menggabungkan penggunaan UAV untuk pengambilan imej multispektral dan juga sistem GIS yang bertujuan untuk mengukur kadar keberkesanan rawatan yang diberi pada tanaman padi. 


\section{Metodologi}

\subsection{Kawasan Kajian dan Informasi Plot Kajian}

Kajian ini meliputi sebahagian kawasan seliaan Lembaga Kemajuan Pertanian Kemubu (KADA) yang terletak di Ladang Merdeka, Ketereh, Kelantan dengan keluasan 20 hektar. Gambar rajah 2 di bawah menunjukkan kawasan kajian secara menyeluruh.

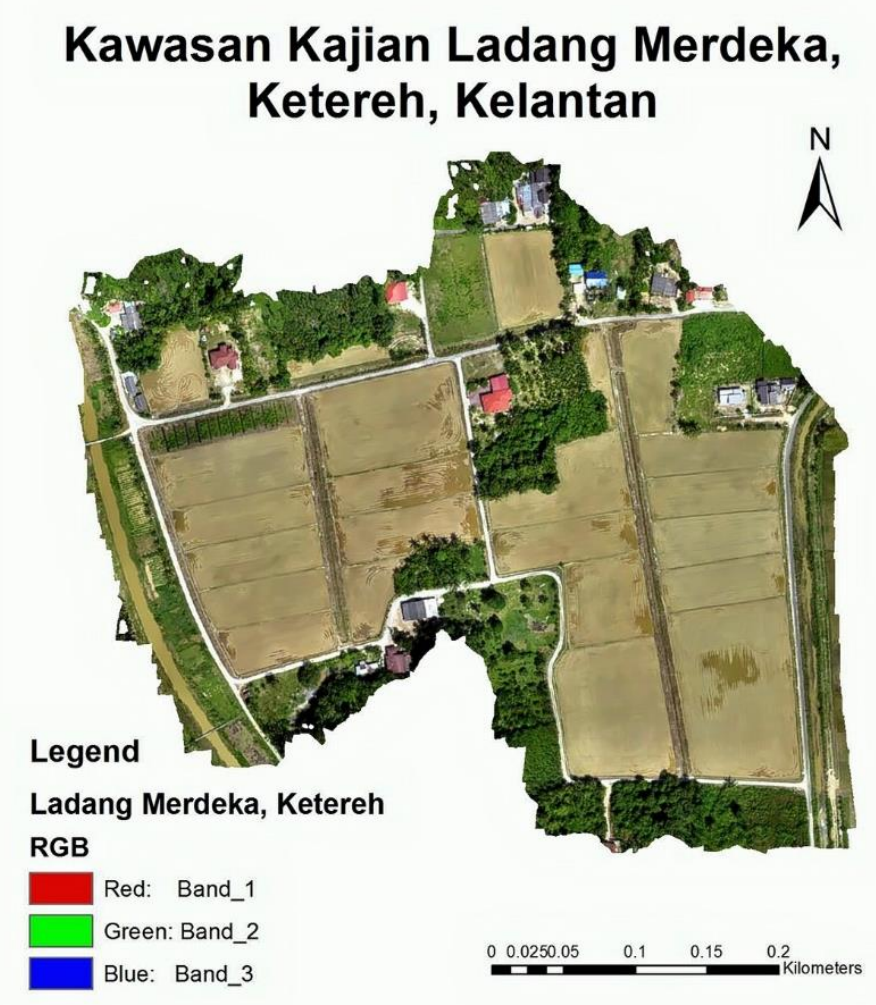

Gambar rajah 2. Gambaran menyeluruh kawasan kajian Ladang Merdeka, Ketereh, Kelantan

Kajian ini menggunakan benih dari PadiU Putra. Terdapat enam jenis plot kawalan yang menggunakan enam jenis pembajaan yang berbeza. Kajian ini menggunakan beberapa jenis pembajaan ke atas petak-petak sawah seperti formulasi di bawah:

1. Kawalan (Control): tanpa sebarang penambahan pembajaan, hormon atau bakteria.

2. Kompos Komersil (Commercial compost): pembajaan penambahan baja kompos sebanyak 3 t/ha yang dilakukan sewaktu persediaan tapak sawah dari kompos sekam padi dari Kilang Beras Bernas, Kelantan.

3. Kompos dengan Inokulum (Compost with Inoculum): kompos dengan penambahan inokulasi bakteria sewaktu persediaan tapak sawah (Mohd Zainudin et al., 2019). 
4. U Grow: aplikasi silikon baja foliar (2500 ppm) pada umur pokok padi 35 dan 55 hari selepas tuai.

5. Mikrob: aplikasi baja foliar bagi merangsang pertumbuhan rhizobakteria pada umur pokok padi 35 dan 55 hari selepas tuai (Mohamad Halid et al., 2019).

6. U-Filler: aplikasi baja foliar bagi hormon berasaskan tumbuhan pada umur pokok padi 35 dan 55 hari selepas tuai (Farooq et al., 2009).

\subsection{Pengambilan Data dan Analisis}

Kajian ini menggunakan data yang diambil menggunakan UAV pada tarikh 28 Mei 2018 iaitu pada hari ke-117 umur tanaman padi. Data diambil pada waktu pagi di antara 8:30 pagi hingga 12:00 tengah hari untuk mengelakkan gangguan angin dan bayang-bayang. UAV diterbangkan pada ketinggian 70 meter dengan nisbah pertindihan imej melebihi $75 \%$. Gambar rajah 3 di bawah menunjukkan carta alir proses yang digunakan dalam kajian ini.

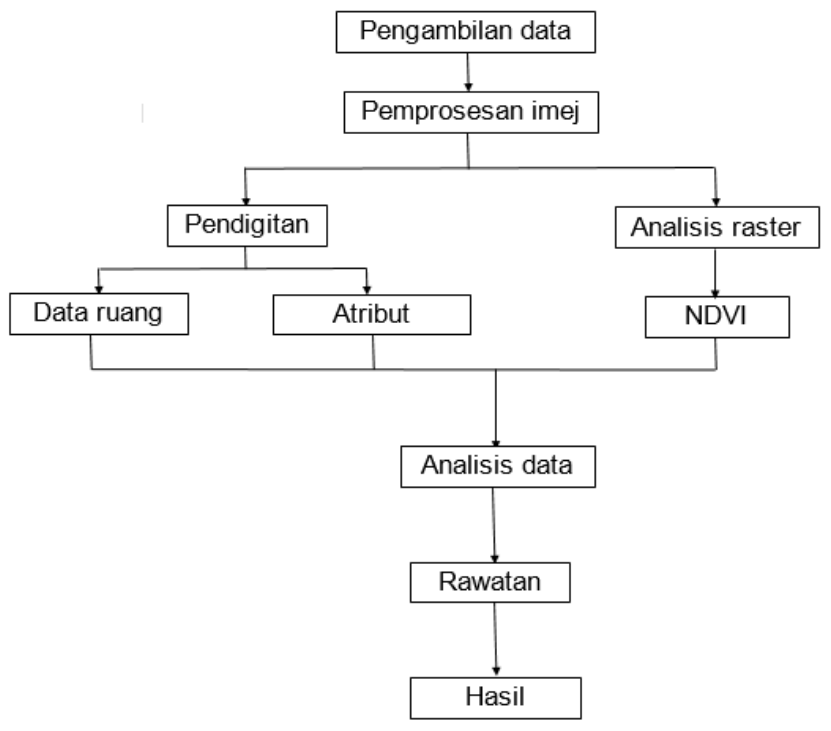

Gambar rajah 3. Carta alir proses yang digunakan dalam kajian

Kajian ini menggunakan UAV jenis XR q350 Pro UAV untuk tujuan pengambilan data. Spesifikasi UAV adalah seperti Gambar rajah 4 di bawah: 


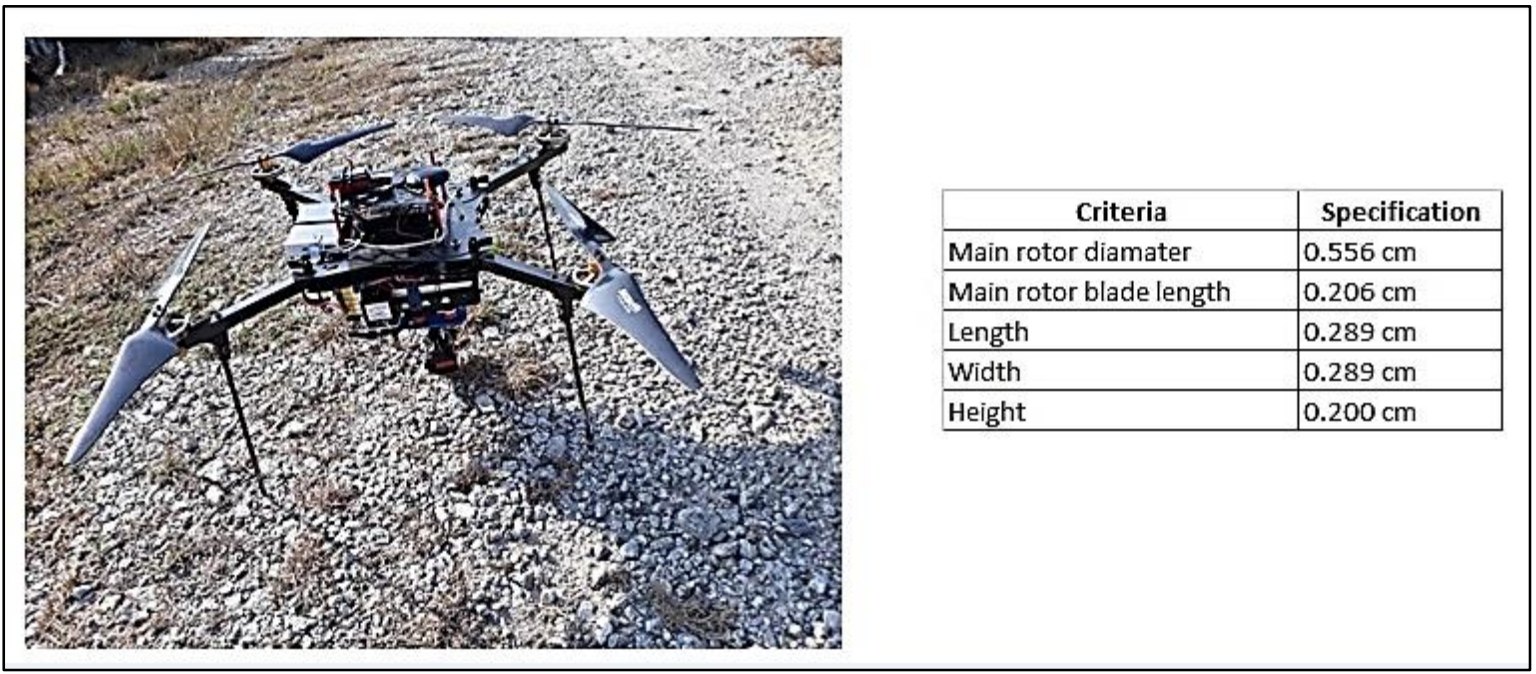

Gambar rajah 4. Spesifikasi XR q350 Pro UAV (Lee, 2019)

Pengambilan data untuk kajian dilakukan sebanyak dua kali iaitu yang pertama alatan UAV disertakan dengan Canon Powershot xs260 untuk pengambilan imej RGB seperti Gambar rajah 5 dan Parrot Sequioa Multispectral Camera untuk pengambilan imej multispektral seperti Gambar rajah 6.

\begin{tabular}{|c|c|c|}
\hline & Canon Powershot xs 260 & \\
\hline & Criteria & Specification \\
\hline & Focal length & $\begin{array}{l}4.5-90.0 \mathrm{~mm} \text { ( } 35 \mathrm{~mm} \text { equivalent: } 25 \text { - } \\
500 \mathrm{~mm} \text { ) }\end{array}$ \\
\hline & Maximum f/number & $F / 3.5-f / 6.8$ \\
\hline $\mathrm{ces}$ & Construction & $\begin{array}{l}12 \text { elements in } 10 \text { groups ( } 1 \text { ua lens, } 2 \\
\text { double-sided a spherical lens) }\end{array}$ \\
\hline & Image stabilization & Yes (lens shift-type), 4-stop. Intelligent is \\
\hline & Effective pixels & Approx. $12.1 \mathrm{~m}$ \\
\hline
\end{tabular}

Gambar rajah 5. Spesifikasi Canon Powershot xs260 (Lee, 2019) 


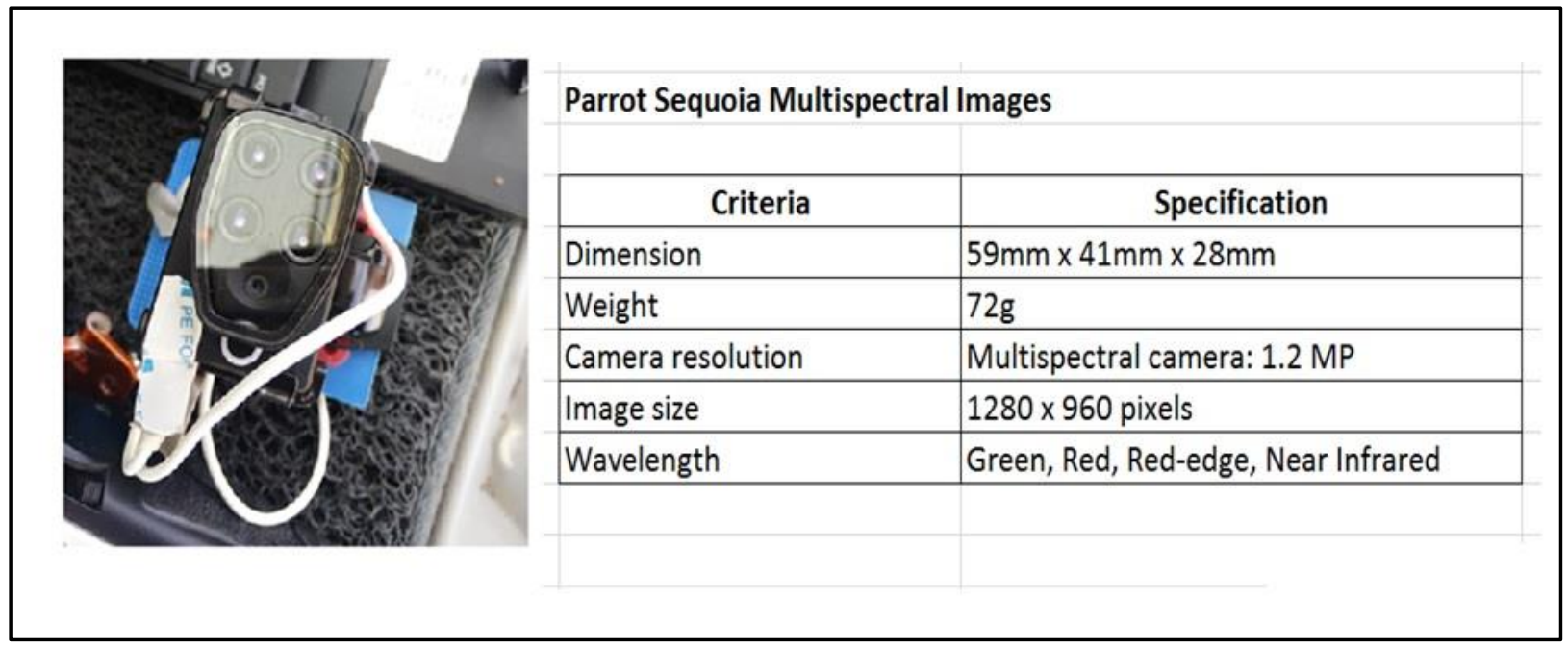

Gambar rajah 6. Spesifikasi Parrot Sequioa Multispectral Camera (www.parrot.com, 2019)

Imej-imej yang diambil kemudiannya diproses menggunakan perisian Agisoft Photoscan untuk menghasilkan ortofoto RGB dan juga imej multispektral. Imej RGB ini akan dipaparkan di dalam perisian ArcGIS 10.2 untuk tujuan penghasilan peta NDVI dan juga pendigitan data vektor seperti Gambar rajah 7, 8 dan 9 di bawah:

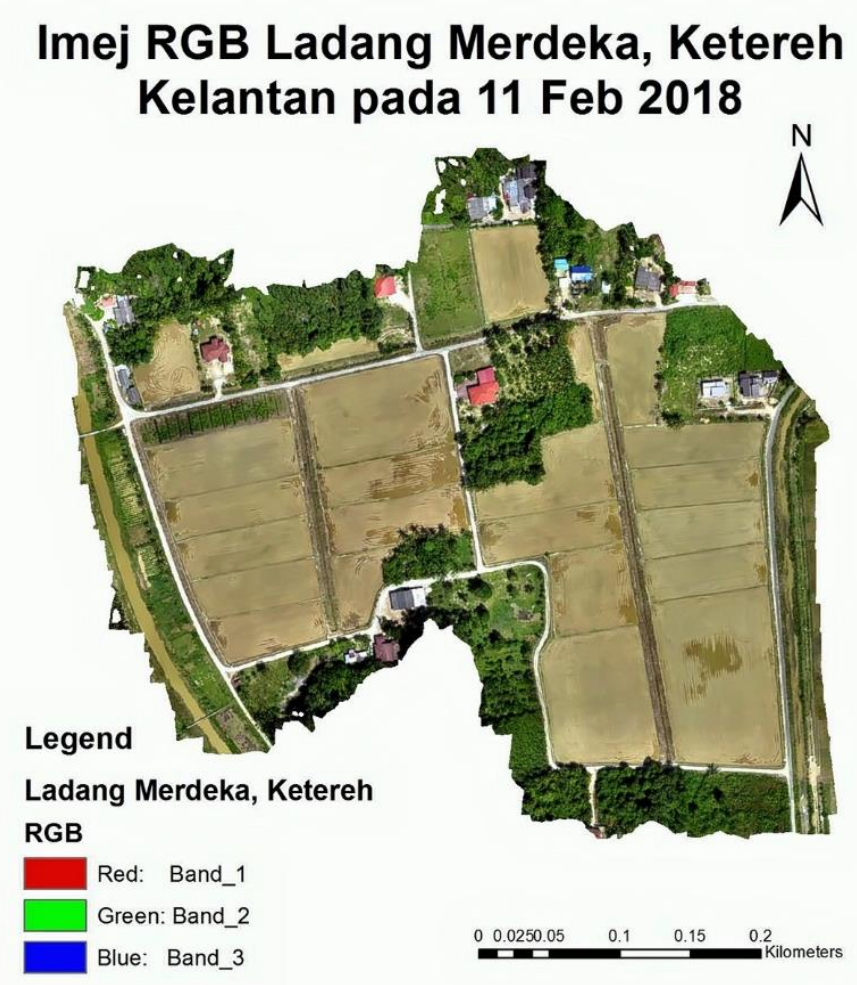

Gambar rajah 7. Gambaran keseluruhan kawasan kajian Ladang Merdeka dalam bentuk ortofoto RGB. 


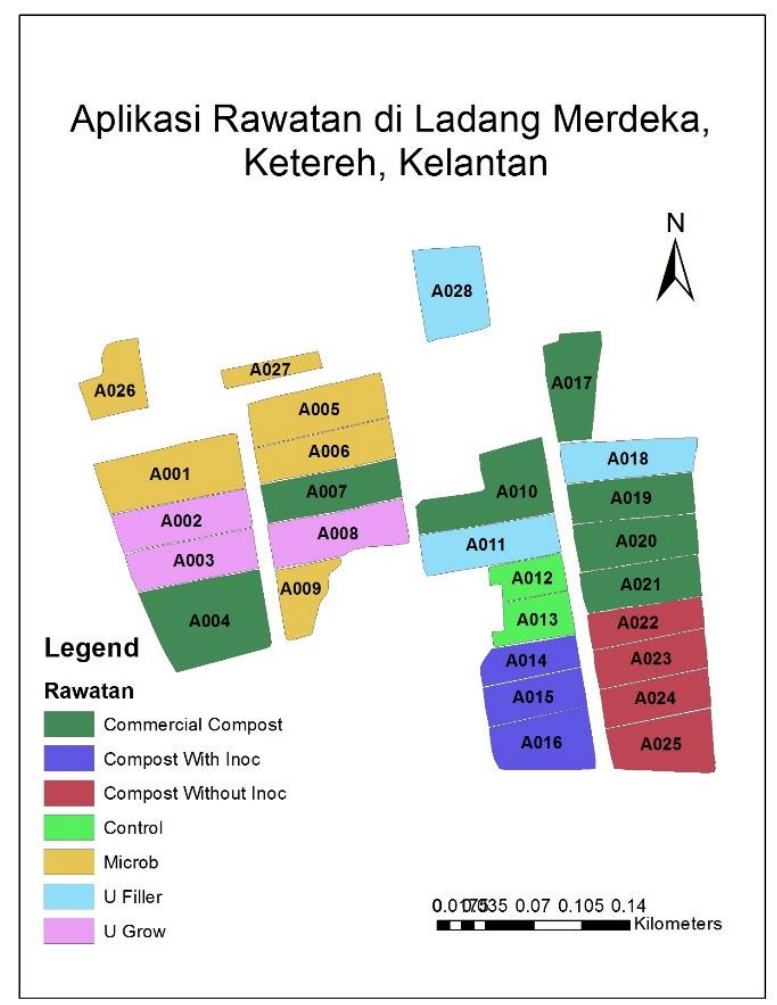

Gambar rajah 8. Data vektor rawatan pada plot kajian yang didigit dari imej RGB menggunakan perisian ArcGIS 10.2.

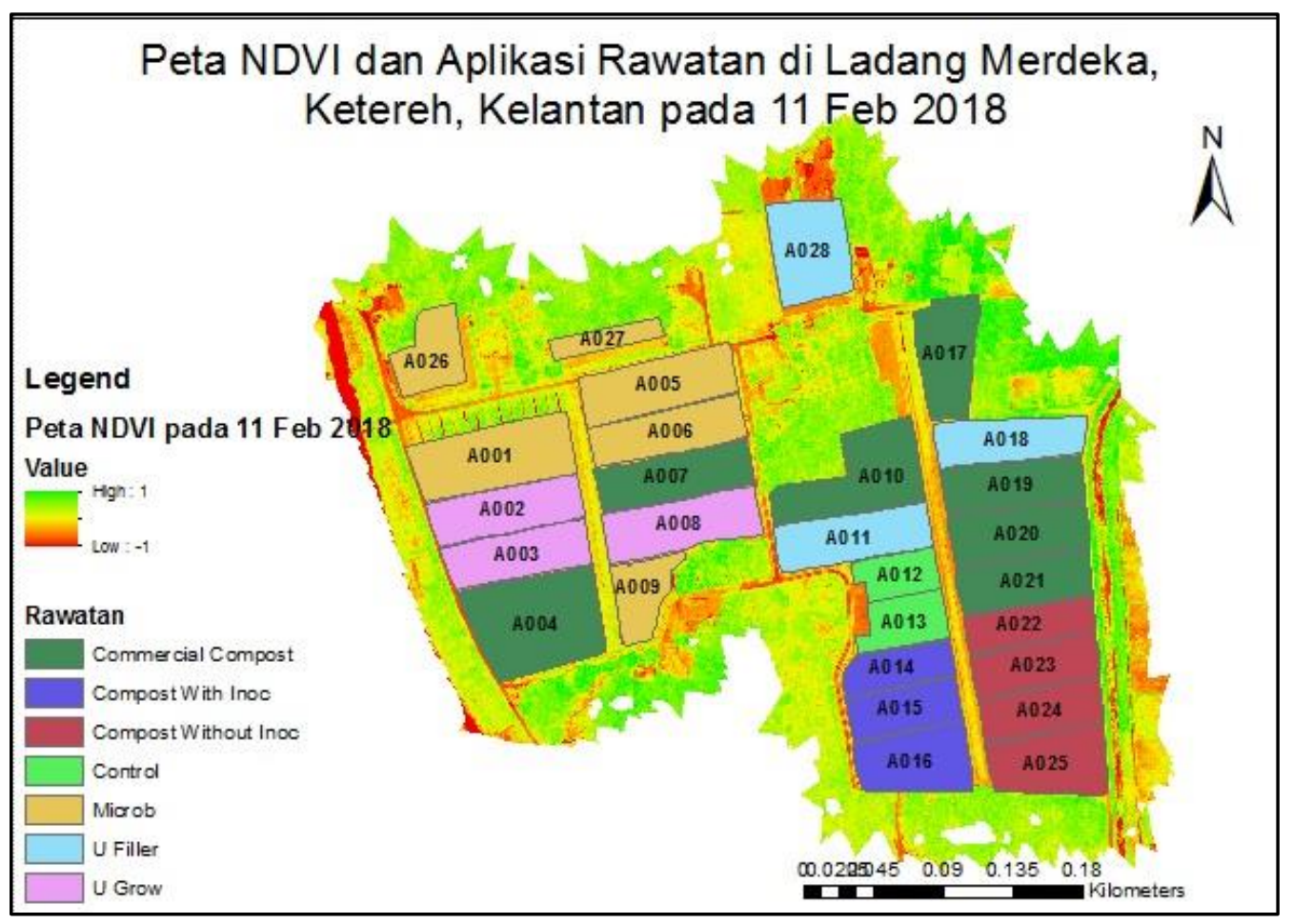

Gambar rajah 9. Peta NDVI yang dihasilkan dari imej multispektral berserta data vektor keseluruhan kawasan kajian. 


\subsection{Indeks Tumbuhan}

Kajian ini menggunakan analisis indeks tumbuhan dengan formula seperti di bawah:

$$
\mathrm{NDVI}=(\mathrm{NIR}-\mathrm{Red}) /(\mathrm{NIR}+\mathrm{Red})
$$

di mana NIR mewakili nilai pantulan jalur infra merah dan nilai $\mathrm{R}$ adalah nilai pantulan dari jalur merah (Vergara-Diaz et al., 2016). Julat bacaan NDVI adalah di antara $-1.0 \mathrm{ke}+1.0$. Bacaan indeks tumbuhan 0 hingga +1.0 memberi indikasi tanaman dalam keadaan sihat atau tidak sihat. Semakin tinggi nilai NDVI semakin sihat keadaan tanaman (Kazuki et al., 2017).

\section{Hasil Kajian dan Perbincangan}

\subsection{Analisis Imej RGB dan Multispektral}

Pertindihan data spatial dan imej RGB memberi gambaran yang lebih jelas mengenai susun atur petak sawah. Gambar rajah 10 di bawah menunjukkan susun atur petak sawah di kawasan kajian berserta label rawatan yang diberi. Dengan menggunakan perisian ArcGIS 10.2, imej multispektral digunakan untuk menghasilkan peta NDVI seperti Gambar rajah 11 di bawah.

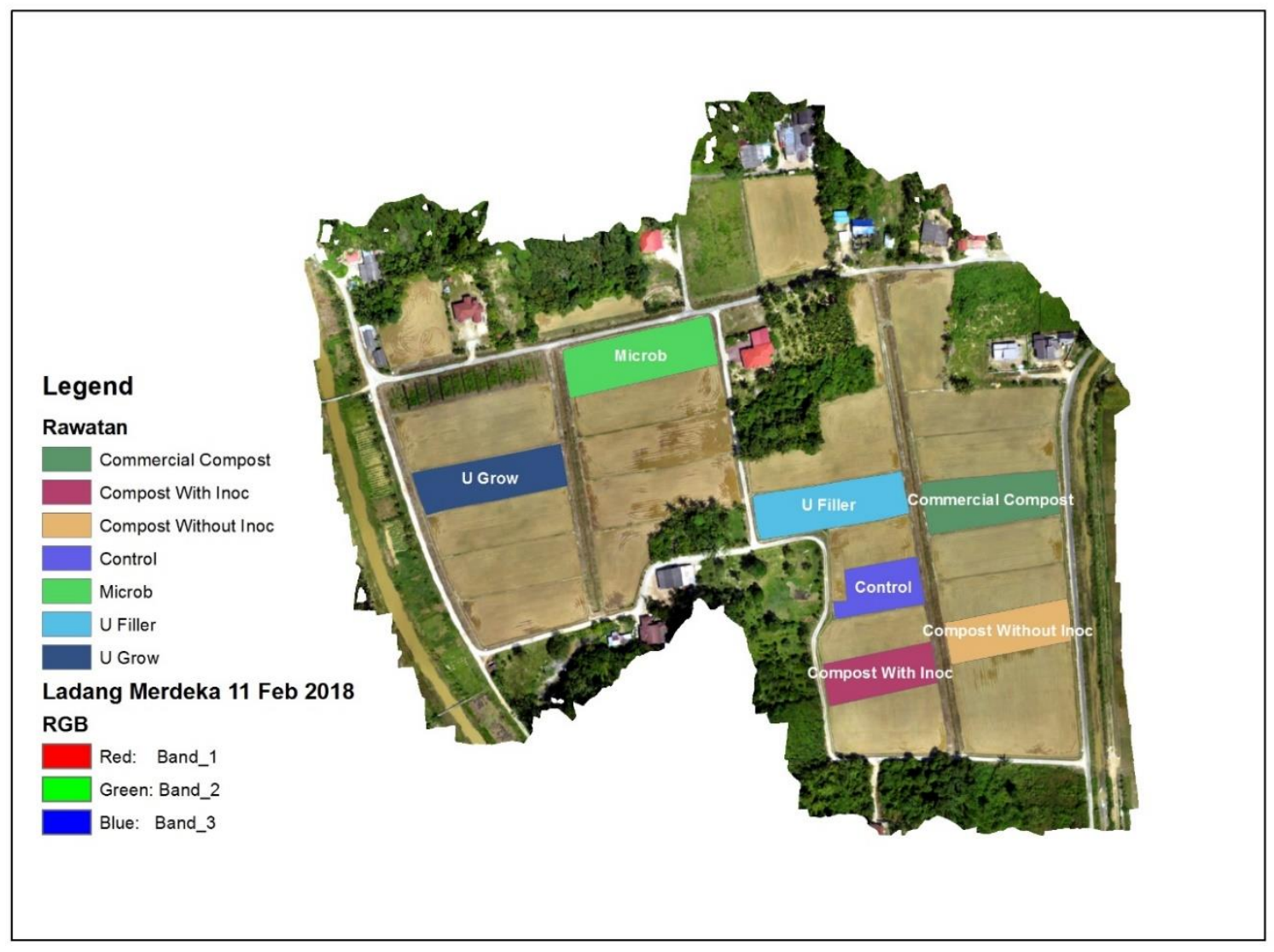

Gambar rajah 10. Kawasan kajian beserta pilihan plot dijana dari imej 


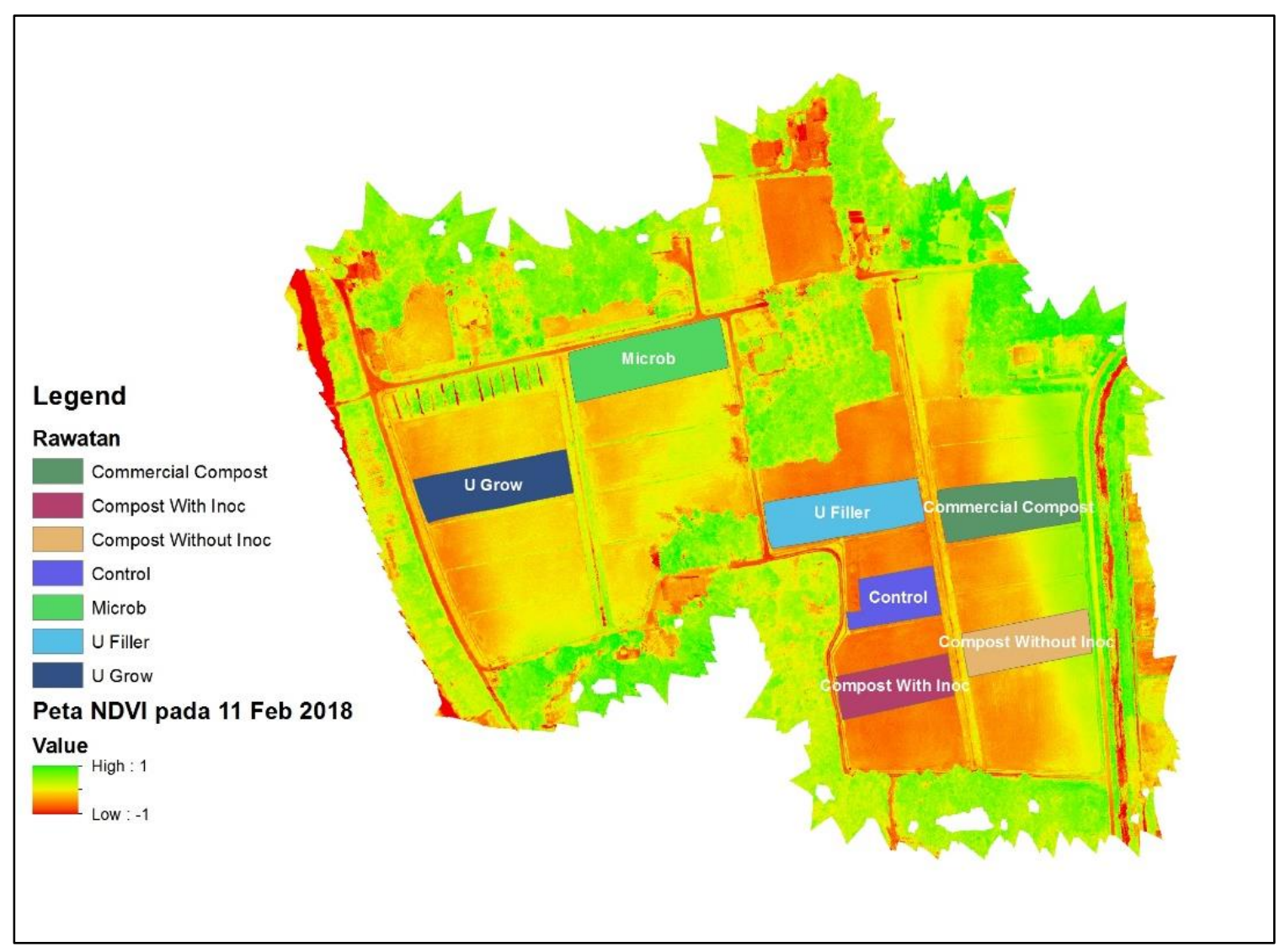

Gambar rajah 11. Peta NDVI yang multispektral berserta pilihan plot

\subsection{Perbandingan Imej RGB dan Peta NDVI Pada Rawatan yang Berbeza}

Keputusan menunjukkan setiap petak sawah menghasilkan nilai bacaan NDVI yang berbeza. Dalam kajian ini, dengan menggunakan data vektor yang dihasilkan dari perisian ArcGIS tadi, imej tersebut dapat diperincikan secara berasingan mengikut jenis rawatan yang diterima pada plot sawah. Pengguna hanya perlu memilih sama ada untuk memaparkan imej RGB atau imej NDVI dari perisian tersebut. Imej RGB dan NDVI bagi jenis rawatan yang berbeza pada plot pada umur pokok padi 117 hari seperti Jadual 1 di bawah. 
Jadual 1. Menunjukkan perbandingan imej RGB dan peta NDVI pada plot rawatan

\begin{tabular}{|l|l|}
\hline \multicolumn{3}{|c|}{ Jenis Rawatan: Kawalan (Control) } \\
\hline \multicolumn{2}{|c|}{ Imej RGB } \\
\hline
\end{tabular}




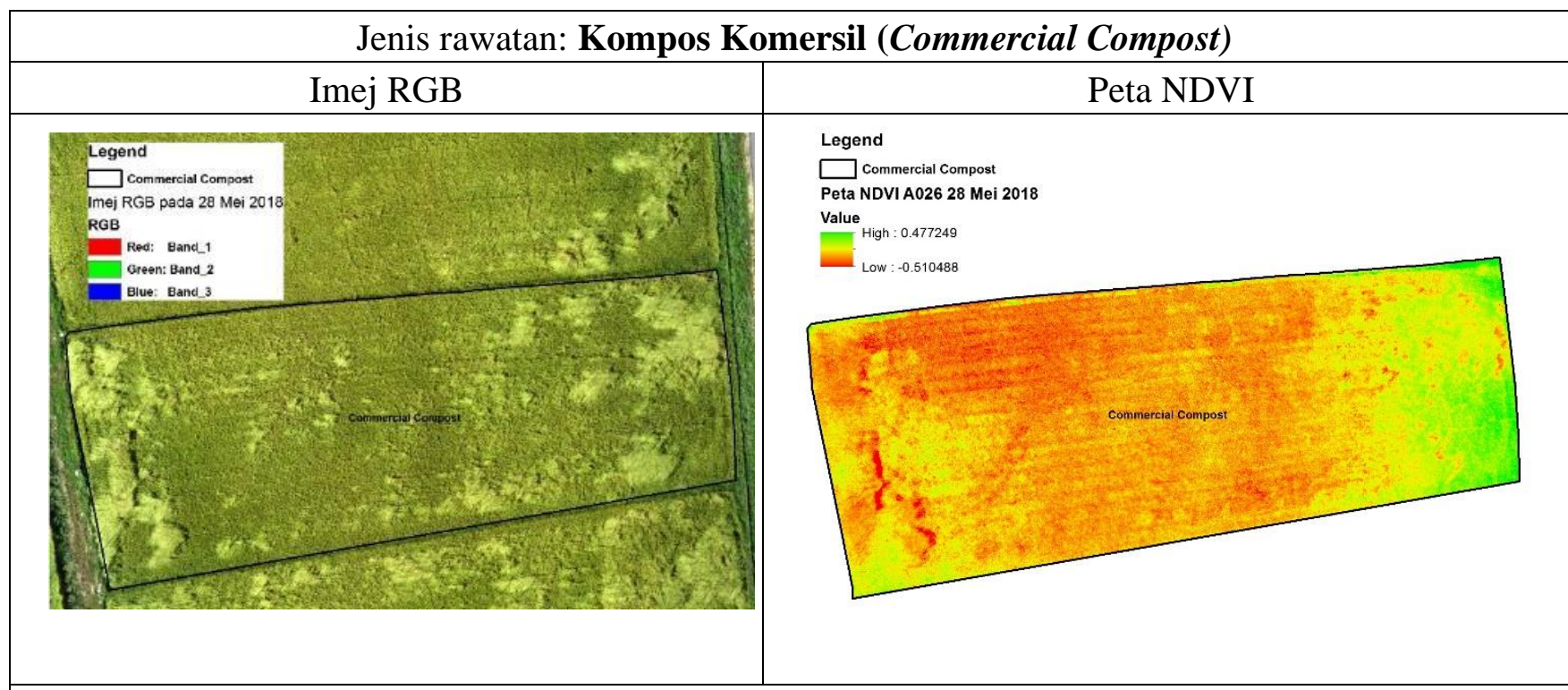

Perbincangan:

Nilai NDVI yang dihasilkan adalah di antara -0.5105 hingga 0.4772. Peta NDVI menunjukkan pertumbuhan tanaman padi adalah tidak seragam. Daripada peta NDVI yang dihasilkan, kawasan hijau masih belum sedia untuk dituai kerana aktiviti fotosintesi masih giat dijalankan untuk menghasilkan benih padi. Ini merupakan kelebihan peta NDVI dalam memantau pertumbuhan tanaman di dalam plot yang mana tidak dapat dilihat dengan jelas dari imej RGB (Kazuki et al., 2017). Namun, sebahagian besar daripada plot juga mengalami kerosakan atau tumbang. Dengan bantuan dari peta NDVI ini, petani boleh melakukan pengawasan di ladang dan merancang hari yang sesuai untuk menuai hasil tanaman.

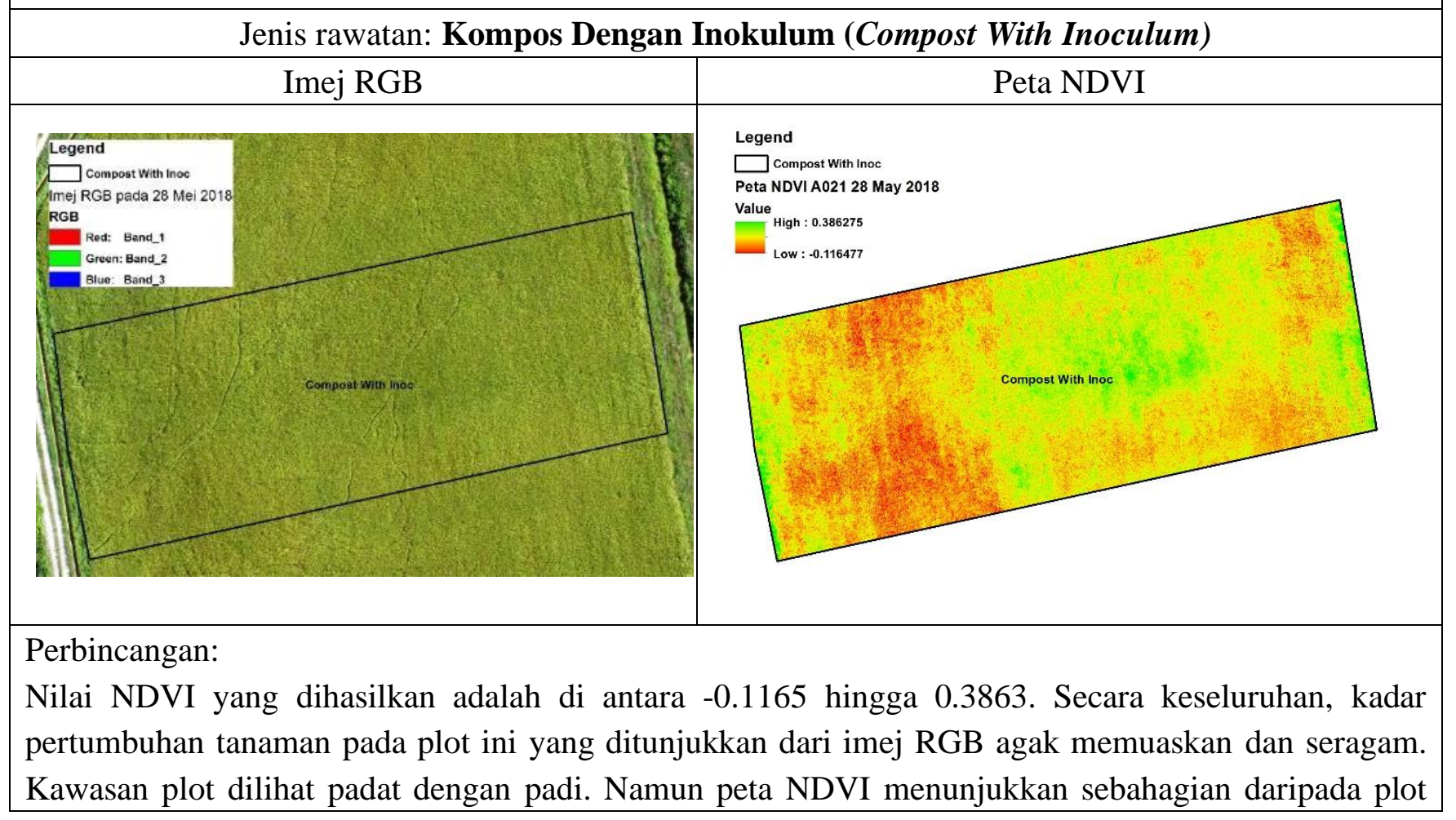




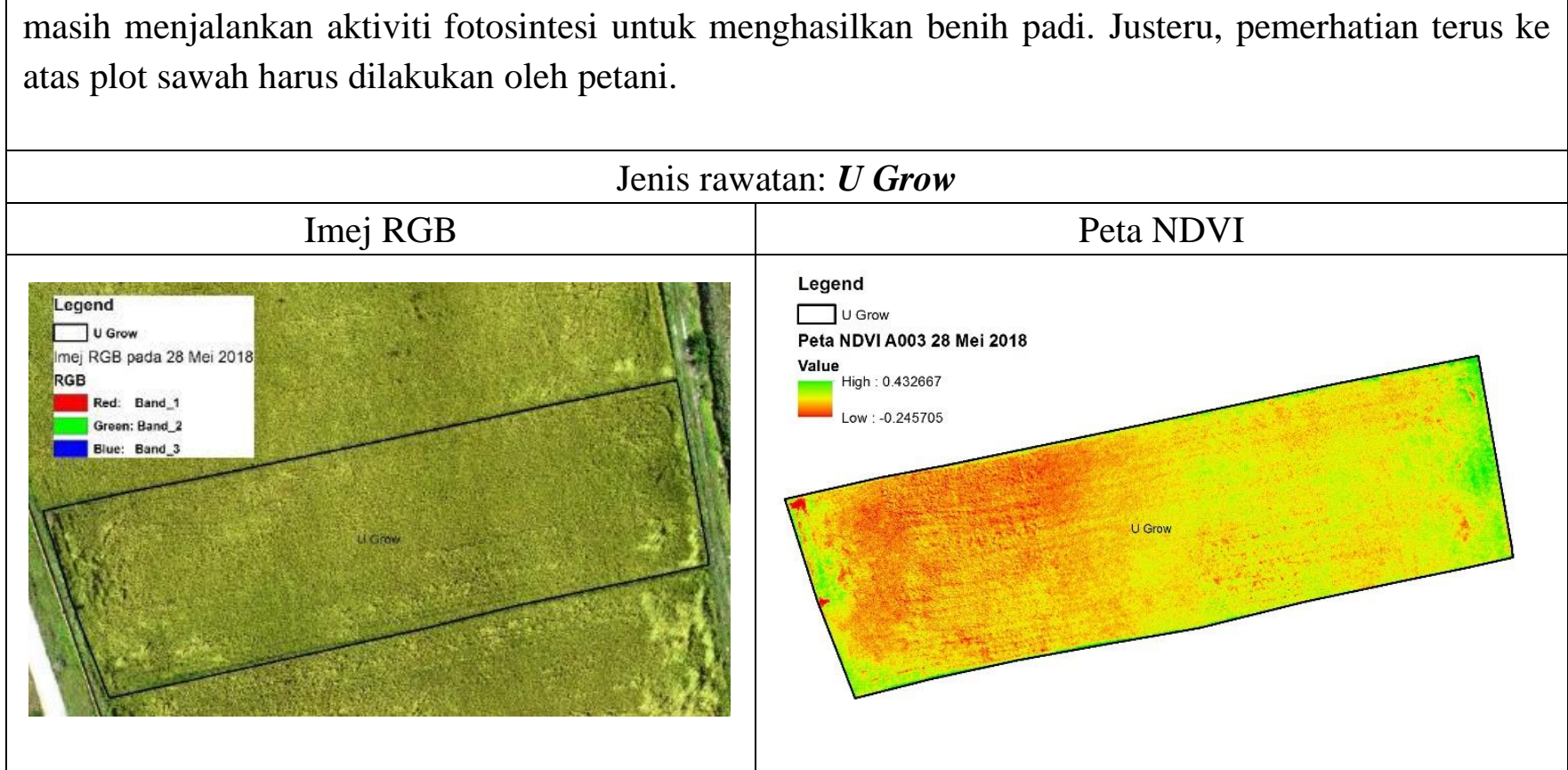

\section{Perbincangan:}

Nilai NDVI yang dihasilkan adalah di antara -0.2457 hingga 0.4327. Imej RGB yang dicerap menunjukkan tahap kerosakan pada plot padi dalam kadar yang agak minimum. Kadar pertumbuhan padi pada bahagian kiri plot adalah baik namun sedikit terjejas pada bahagian kanan dan sudut kiri plot. Indikasi warna kuning dan jingga pada peta NDVI menunjukkan kadar pertumbuhan yang normal. Maka, petani boleh menghadkan kawasan pemantauan hanya pada kawasan yang berindikasi warna hijau dari peta NDVI.

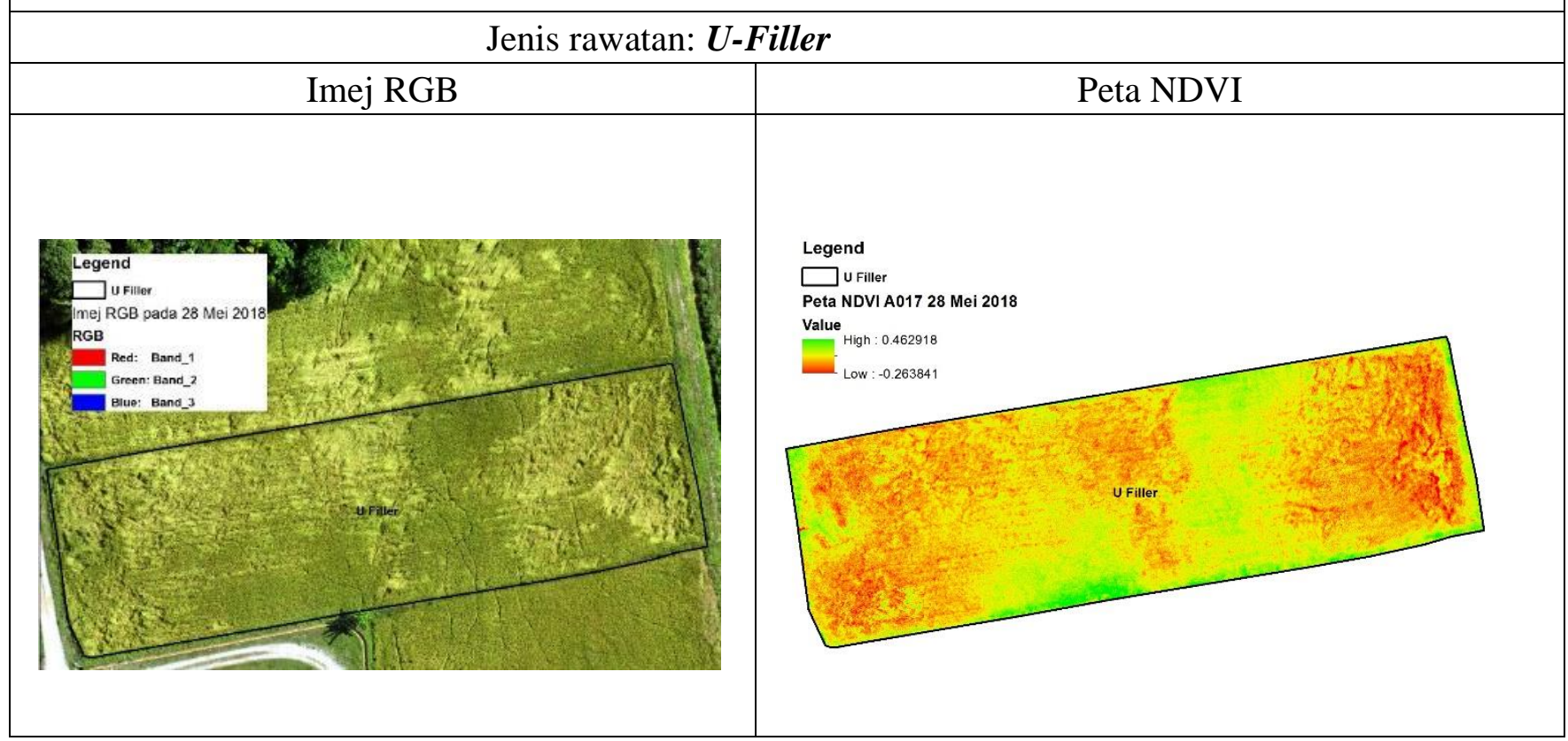




\begin{abstract}
Perbincangan:
Nilai NDVI yang dihasilkan adalah di antara -0.2638 hingga 0.4629. Imej RGB menunjukkan jelas kadar kerosakan tanaman yang melebihi $50 \%$ daripada plot. Trend tanaman tidak sihat ini dapat juga dilihat melalui peta NDVI yang dihasilkan dengan merujuk kepada warna kuning dan jingga hampir di keseluruhan plot. Kerosakan yang diekstrak dari peta NDVI adalah signifikan dengan imej cerapan RGB.

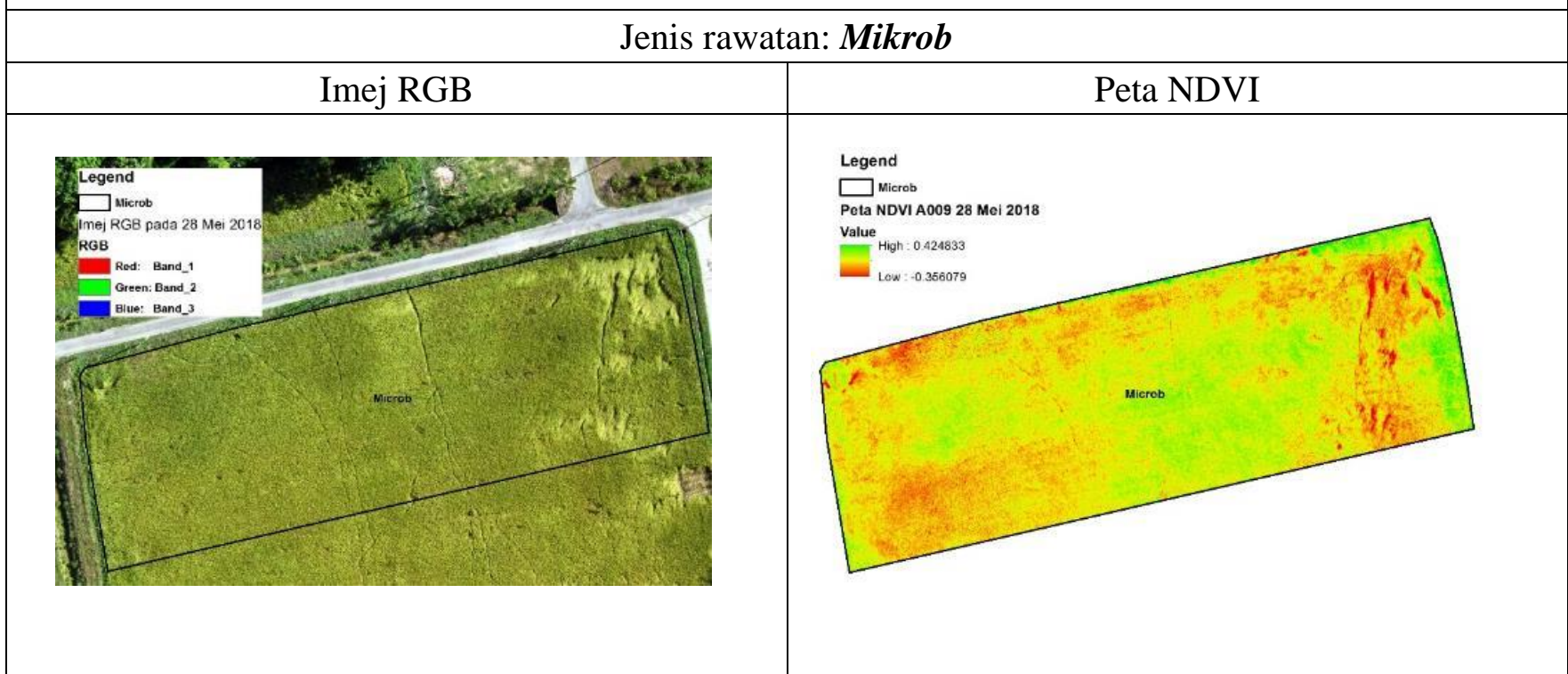

Perbincangan:

Nilai NDVI yang dihasilkan adalah di antara -0.3561 hingga 0.4248 . Secara keseluruhan plot ini menunjukkan pertumbuhan yang agak baik yang boleh dilihat dari imej RGB kecuali di bahagian penjuru kanan plot. Sebahagian plot berindikasi warna kuning dan merah pada peta NDVI menunjukkan tanaman telah matang dan telah memasuki fasa sedia untuk dituai. Ianya juga boleh dilihat dengan jelas dari imej RGB. Dengan ini, petani boleh meminimumkan aktiviti penyelenggaraan pada bahagian tertentu sahaja.
\end{abstract}

\title{
3.3. Hasil Padi Daripada Mesin Penuai
}

Setelah pokok padi mencapai tahap kematangan bijian sehingga $80 \%$, setiap petak sawah padi akan dituai secara berasingan. Pada akhir kajian, hasil padi dapat ditentukan daripada tiga replikasi dari rawatan yang digunakan (120 hari selepas tanam). Hasil padi akan dituai berasingan mengikut tapak sawah menggunakan mesin penuai, diangkut dari sawah menggunakan lori yang berasingan dan berat hasil tuaian akan ditimbang di kilang padi secara berasingan di Padiberas Nasional Berhad (BERNAS Sdn Bhd). Hasil dari jumlah tuaian

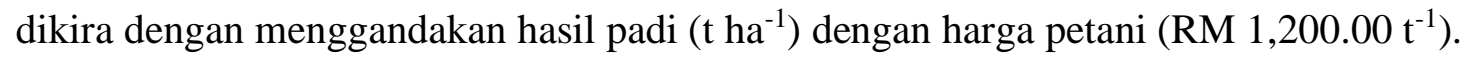




\subsection{Korelasi Antara NDVI Dan Rawatan}

Analisis dan hasil menunjukkan bahawa hasil yang paling tinggi adalah dari plot rawatan kompos dengan inokulum dengan hasil $2494.73 \mathrm{~kg} / \mathrm{ha}$ manakala plot dari rawatan kompos komersil mempunyai hasil tuaian yang paling rendah iaitu $732.10 \mathrm{~kg} / \mathrm{ha}$. Ianya diikuti dengan $U$ Grow, kawalan, $U$-Filler dan Mikrob. Kajian imej analisis menunjukkan bahawa kadar bacaan NDVI yang tinggi menandakan pokok padi tersebut masih aktif menjalankan aktivi fotosintesis dan masih belum bersedia untuk dituai. Nilai NDVI pada tanaman adalah berbeza-beza mengikut tahap kesihatan dan pertumbuhan tanaman itu sendiri (Wakamori, et al., 2017). Peta NDVI sesuai digunakan sebagai rujukan untuk memantau pertumbuhan tanaman serta mengesan lokasi sebarang kerosakan pada plot tanaman (Rosle, et al., 2019). Daripada hasil kajian mendapati bahawa bacaan maksimum NDVI pada plot kompos komersil mempunyai nilai NDVI maksimum 0.4177 iaitu lebih tinggi daripada bacaan NDVI pada plot kompos dengan inokulum dengan bacaan NDVI maksimum 0.3863. Kedua-dua plot ini mempunyai perbezaan nilai bacaan NDVI maksimum sebanyak 0.0313. Namun perbezaan hasil antara kedua-dua plot ini sangat tinggi sehingga melebihi $1700 \mathrm{~kg} / \mathrm{ha}$.

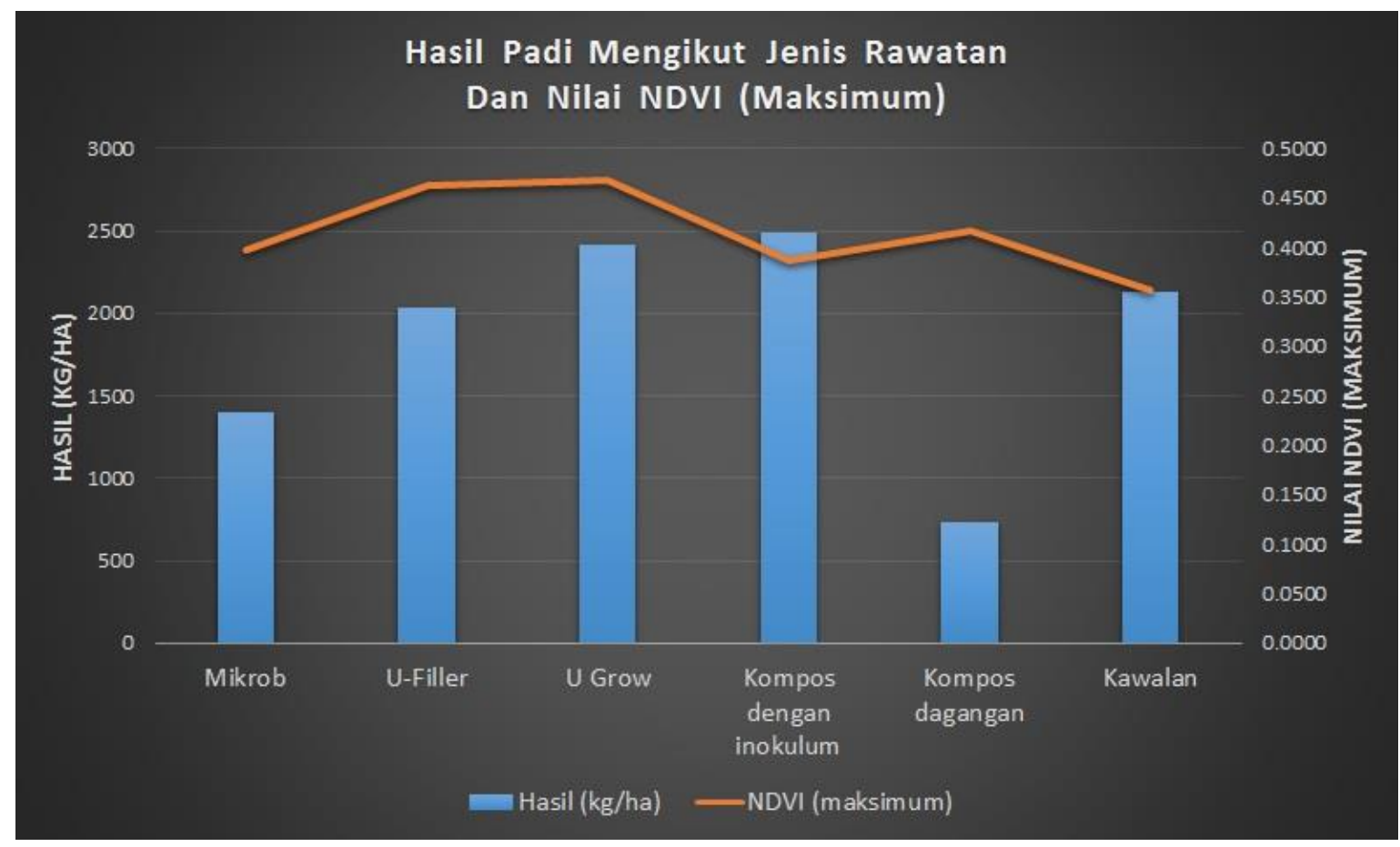

Gambar rajah 12. Graf hasil tuaian dan nilai NDVI (maksimum) bagi setiap rawatan

Gambar rajah 13 di bawah menunjukkan bacaan nilai NDVI (min) pada plot padi mengikut jenis rawatan dan umur pokok padi. Secara keseluruhannya, nilai NDVI akan beransur meningkat dari awal pertumbuhan dan semakin meningkat pada peringkat 
pembungaan. Nilai NDVI akan kembali menurun menjelang tempoh penuaian (Mosleh, et al., 2015). Untuk kajian ini, data lapangan yang dicerap dari Soil Plant Analysis Development (SPAD) chlorophyll meter adalah terhad seperti gambar rajah 14. Nilai bacaan SPAD yang diperolehi menunjukkan bacaan berkadar terus pada awal pertumbuhan padi di mana ianya adalah selari juga dengan nilai bacaan NDVI pada awal pertumbuhan tanaman. Nilai NDVI semakin meningkat selari dengan kadar kandungan klorofil pada tanaman. Semakin tinggi kandungan klorofil dalam tanaman semakin tinggi bacaan NDVI (Hashemi \& Chenani, 2011).

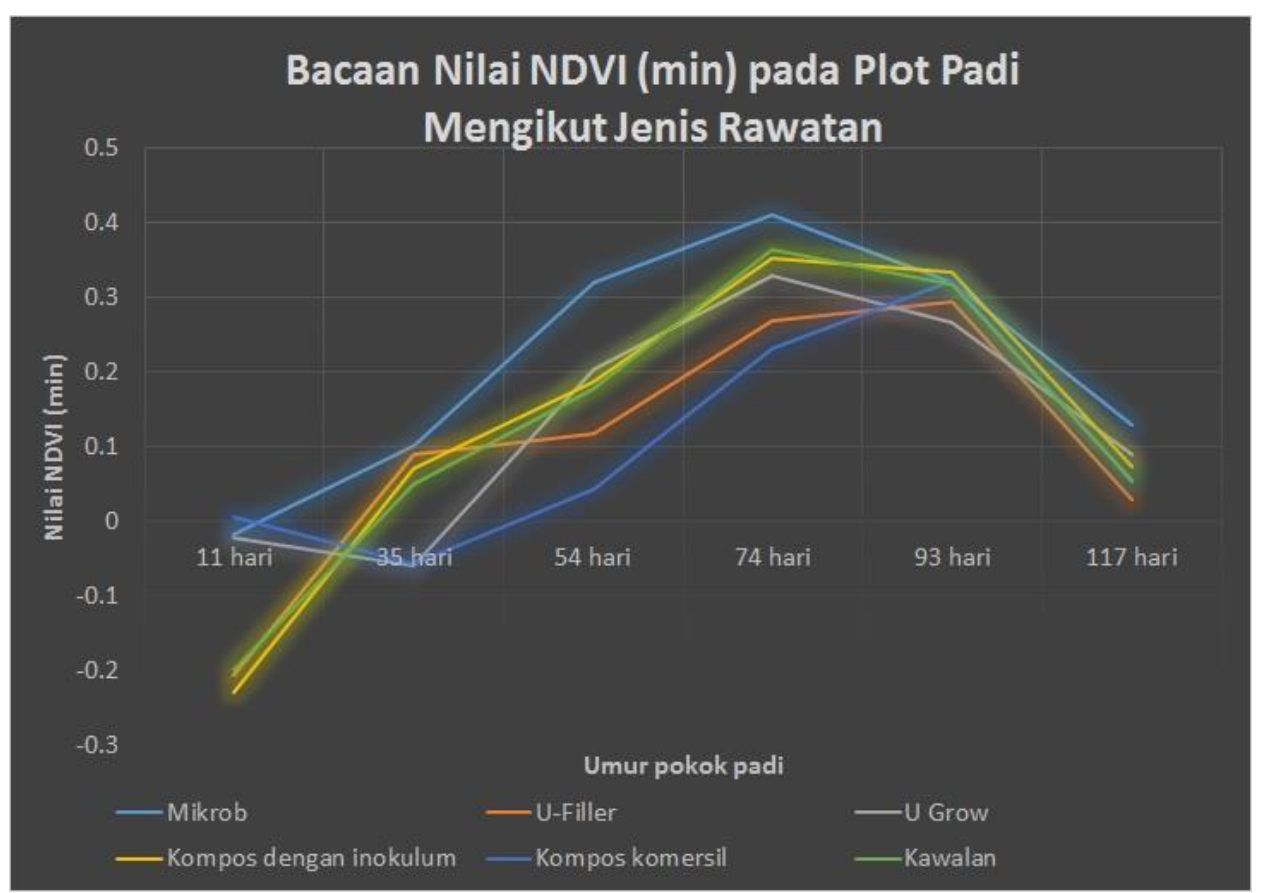

Gambar rajah 13. Bacaan nilai NDVI (min) pada plot padi mengikut jenis rawatan

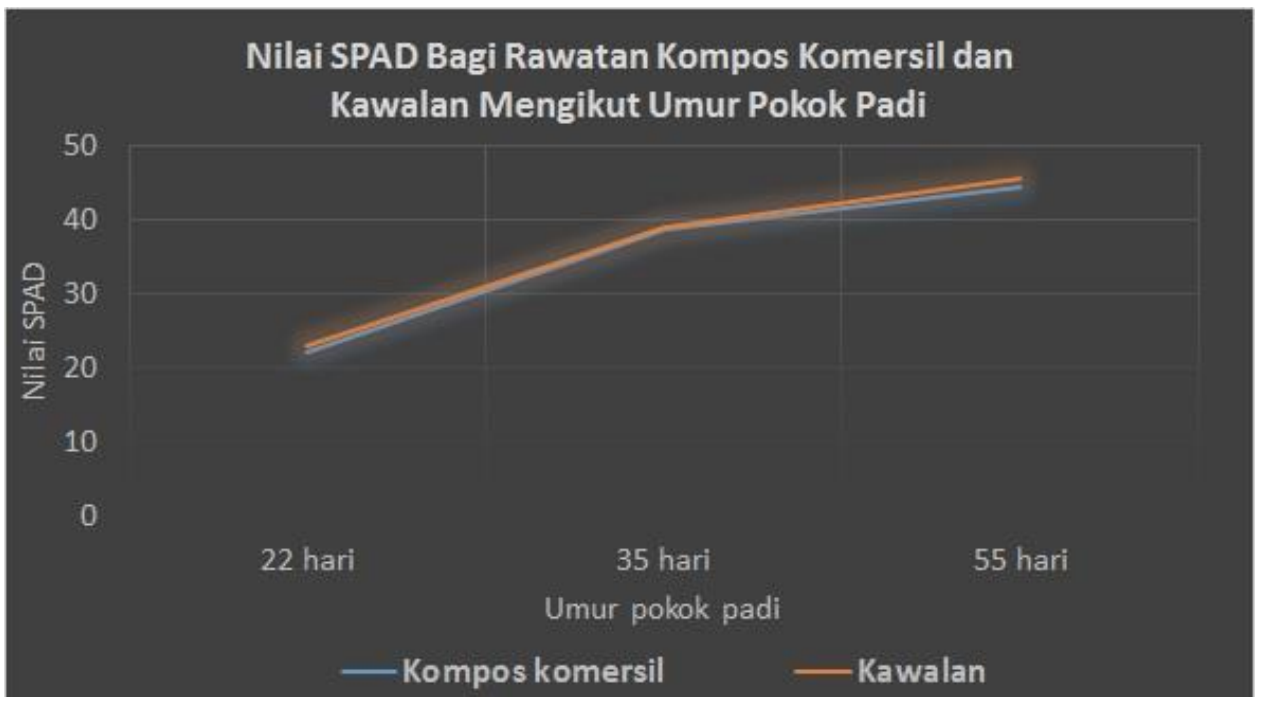

Gambar rajah 14. Bacaan nilai SPAD bagi rawatan jenis kompos komersil (Commercial Compost) dan kawalan (Control) mengikut umur pokok padi 


\section{Kesimpulan}

Analisis menunjukkan rawatan jenis kompos dengan inoculum adalah rawatan paling berkesan dalam meningkatkan hasil tanaman padi berbanding lima jenis rawatan yang lain. Imej analisis pula menunjukkan kadar bacaan NDVI yang tinggi menandakan pokok padi tersebut masih aktif menjalankan aktivi fotosintesis dan masih belum sedia untuk dituai. Bacaan NDVI ini boleh dijadikan sebagai penanda aras untuk tujuan pemantauan tahap pertumbuhan tanaman padi. Peta NDVI perlu dilihat secara menyeluruh melalui indikasi warna yang dihasilkan untuk memastikan tahap pertumbuhan tanaman. Hasil menunjukkan bahawa imej RGB dapat mempamerkan plot tanaman secara menyeluruh dan peta NDVI dapat memberi indikasi sekiranya berlaku kerosakan di dalam kawasan tanaman padi tersebut dan pada masa yang sama memantau sekiranya tanaman masak dengan seragam atau tidak. Petani boleh menumpukan kepada kawasan tanaman padi yang tidak seragam berdasarkan peta NDVI bagi tujuan pemantauan. Bagi tujuan kajian yang lebih efektif, data lapangan dari Greenseeker perlu diambil bagi tujuan perbandingan dengan peta NDVI yang dihasilkan dari perisian komputer.

Pemberitahuan: Penyelidik berterima kasih di atas bantuan sokongan daripada En. Mohd Zalyny Shah b. Noh, En Nasir Abd Rani dan juga sokongan kewangan daripada Kementerian Pendidikan Tinggi untuk projek "Translational Research GrantTr@M PadiU Putra: Accelerating Rice Food Security and Socio-Economics for Rice Farming Communities" (Vote: 5526500 dan UPM GP-IPM (Vote: 9611400).

Konflik kepentingan: Penulis mengesahkan tiada konflik kepentingan di dalam terbitan ini.

\section{References}

Abd Mutalib, Z. (2019, Ogos 6). MADA, KADA mula pelan tindakan dasar penyatuan tanah sawah. Berita Harian. https://www.bharian.com.my/berita/nasional/2019/08/593306/mada-kada-mula-pelan-tindakan-dasar-penyatuantanah-sawah.

Bhumika, K., Vadher, B. M., \& Agnihotri, P. G. (2019). Application of remote sensing and GIS in cropping pattern mapping: A case study of Olpad Taluka, Surat. GRD Journal - Emerging Research and Innovations in Civil Engineering. 4(9), 343-348.

Faranak Ghobadifar. (2015). Pest attack determination in paddy areas using multispectral remote sensing images [Thesis]. Universiti Putra Malaysia.

Farooq, M., Wahid, A. \& Lee, D. (2009). Exogenously applied polyamines increased drought tolerance of rice by improving leaf water status, photosynthesis and membrane properties. Acta Physiologiae Plantarum, 31(5), 937-945.

Guan, S., Fukami, K., Matsunaka, H. et al. (2019). Assessing correlation of high-resolution NDVI with fertilizer application level and yield of rice and wheat crops using small UAVs. Remote Sensing, 11(2), 112.

Hashemi, S. A. \& Chenani, S. K. (2011). Investigation of NDVI index in relation to chlorophyll content change and phenological event. Recent Advances in Environment, Energy Systems and Naval Science, 22-28.

Jabatan Pertanian. (2019). Booklet statistik tanaman 2019. Dicapai dari http://www.doa.gov.my/index/resources/aktiviti_sumber/sumber_awam/maklumat_pertanian/perangkaan_tanaman/ 
booklet_statistik_tanaman_2019.pdf.

Kazuki, M., Atsushi, I., Hiroyuki, H., et al. (2017). A study on growth condition analysis of rice using drone. Pan Pacific Conference on Science, Computing and Telecommunications (PACT) 2017.

Kementerian Pertanian dan Industri Asas Tani. (2019). Halatuju Kementerian Pertanian \& Industri Asas Tani: Prioriti \& Strategi 2019-2020. Dicapai dari https://www.moa.gov.my/documents/20182/139717/Hala+Tuju+20192020_LowVer.pdf/1ca7c2b3-f4fb-460a-8e04-1fdd051360cb.

Lee, L. S. (2019). Rice monitoring using OBIA technique based on aerial imagery [Thesis]. Universiti Putra Malaysia.

Mahajan, U., \& Bundel, B. R. (2017). Drone for normalized difference vegetation index (NDV) to estimate crop health for precision agriculture: a chapter alternative for spatial satellite sensors. International Conference on Innovative Research in Agriculture, Food Science, Forestry, Horticulture, Aquaculture, Animal Sciences, Biodiversity, Ecological Sciences and Climate Change (AFHABEC-2016).

Mohamad Halid, R, Berahim, Z., \& Mohd Saud, H. (2019). Effects of inoculation of plant growth promoting rhizobacteria to minimize panicle grain shattering habit for increased yield of rice (Oryza sativa L.). African Journal of Microbiology Research, 13(13), 256-263.

Mohd Zainudin, M. H., Mustapha, N. A., Hassan, M. A., et al. (2019). A highly thermostable crude endoglucanase produced by a newly isolated thermobifida fusca strain UPMC 901. Scientific Reports, 9, 13526.

Mosleh, M. K., Hassan, Q. K., \& Chowdhury, E. H. (2015). Application of remote sensors in mapping rice area and forecasting its production: A review. Sensors, 15(1): 769-791.

Murugan, D., Ahmed, A., Greg, A. et al. (2016). Fusion of drone and satellite data for precision agriculture monitoring. $11^{\text {th }}$ International Conference on Industrial and Information System (ICIIS).

Norasma, C. Y. N., Abu Sari, M. Y., et al. (2018). Rice crop monitoring using multirotor UAV and RGB digital camera at early stage of growth. IOP Conference Series: Earth and Environmental Science, 169(2018), 012095.

Parrot.com. (2019). Dicapai dari https://www.parrot.com/global/parrot-professional/parrot-sequoia

Rosle, R., Che' Ya, N. N., Roslin, N. A., et al., (2019). Monitoring early stage of rice crops growth using normalized difference vegetation index generated from UAV. IOP Conference Series: Earth and Environmental Science, 355(1), 012066 .

Sabarina, K., \& Priya, N. (2015). Lowering data dimensionality in big data for the benefit of precision agriculture. Procedia Computer Science, 48(2015); 548-554.

Srinivasan, A. (2006). Handbook of Precision Agriculture: Principles and Applications. CRC Press.

Vergara-Diaz, O., Zaman-Allah, M. A., Masuka, B., et al. (2016). A novel remote sensing approach for prediction of maize yield under different conditions of nitrogen fertilization. Frontiers in Plant Science, 7, 666.

Wakamori, K., Ichikawa, D., Oguri, N., et al. (2017). Estimation of rice growth status, protein content and yield prediction using multi-satellite data. IEEE International Geoscience and Remote Sensing Symposium (IGARSS). 